\title{
James H. Schwartz
}

J ply a wonderful person and one of the most interesting, accomplished, and generous people I have ever known.

I first met Jimmy in 1951 at Harvard Summer School, when he, Bob Goldberger, Henry Nunberg, Robert Spitzer, and I shared a large house. Jimmy and I rapidly became friends, based in part on our common interest in music and German literature.

One year later, in the fall of 1952, I began medical school at NYU. To my delight, I was joined over the next two years by Bob Spitzer and then by Jimmy and Bob Goldberger.

Jimmy's talent for science was evident from the very beginning. While still a student, he carried out an outstanding set of studies with Werner Maas on feedback inhibition in bacterial metabolism. This work was so impressive that, upon completing medical school, Jimmy was nominated to apply to the highly selective graduate program in biology that had just been established at the Rockefeller by Detlev Bronk.

Jimmy readily qualified for this program, which also included in its first few classes Gerald Edelman, Ed Reich, Bertil Hille, and Chuck Stevens, among other future giants of biology. At the Rockefeller, Jimmy obtained his $\mathrm{PhD}$ under the direction of the Nobel laureate Fritz Lipmann, working on bacterial enzyme mechanisms and the control of protein synthesis.

By the time he graduated from Rockefeller, Jimmy had established himself as an outstanding biochemist. He was recruited back to NYU in 1965 as an assistant professor in the Department of Microbiology. The same year, I was recruited to NYU from Harvard.

When Jimmy and I met again at NYU, we talked often about science, and he mentioned that he was thinking of switching from studying bacteria to working on the brain. Because the nerve cells of the snail Aplysia, which I was studying, were so large and uniquely identifiable, they seemed to Jimmy like good candidates for a study of biochemical identity - that is, how one nerve cell differs from another at the molecular level. This gave rise to a classic set of studies, the Giller-Schwartz papers that pioneered the biochemistry of Aplysia.

The immediate success of these papers encouraged Jimmy to devote himself to the nervous system. He rapidly became one of the leading biochemists studying the ner- vous system and one of the leading thinkers on the relationship of the brain to behavior. It is easy to think of at least four contributions that Jimmy made during the course of his career that are central to brain science as we know it today. First, his discovery of the role of cAMP signaling during learning was fundamental for the molecular understanding of memory storage and led to his later being recruited to the Howard Hughes Medical Institute, together with Richard Axel and myself.

Second, his interest in bringing biochemistry to bear on behavior was fundamental to the formation of the first Center for Neurobiology and Behavior in this country - initially at NYU and later at Columbia.

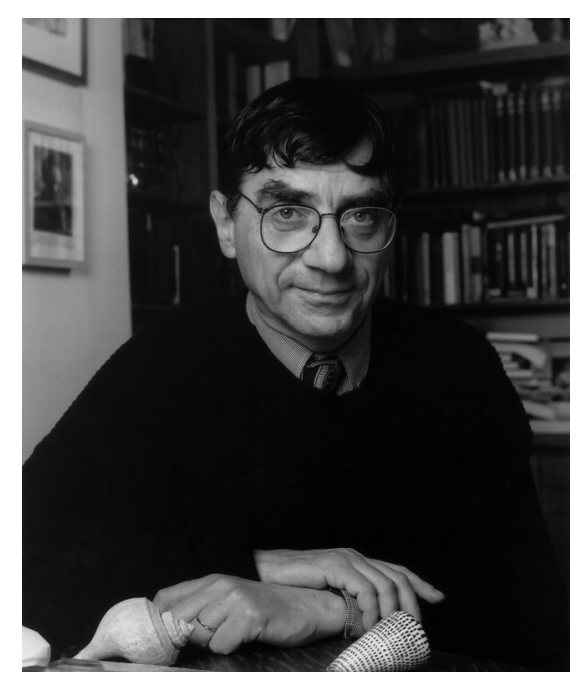

Third, the idea of going from molecules to behavior was the organizing theme of the neural science course that Jimmy helped develop at Columbia. This course was the first that made the study of behavior a central focus in the teaching of neural science to medical students.

Fourth, that course gave rise to Principles of Neural Science, the textbook that many of you know and love. Jimmy contributed enormously to each of the five editions. With each edition, his editorial demands became greater. Jimmy was a superb writer - he loved precision in language. This made him an extraordinary editor.

We worked together on the current edition until the very end. Jimmy was never satisfied with any of the chapters. Tom Jessel, Steve
Siegelbaum, Seta Izmirly, and I would roar with laughter as Jimmy's scathing handwritten comments arrived on our desks. On one chapter he wrote, "This undoubtedly is the worst chapter ever." On another, "I don't think I should see this chapter for a while: it seems to get worse each time." On a third, "The organization of this chapter is fine - its main problem is style of writing - almost always hyper-inflated and 'fancy,' and usually a bit unclear - I don't think it should go back to the authors - they will only translate it back into the language used for drug advertisements." Some of the best barbs were meant for me: "I really don't like this chapter, partly because of the things you say, but mostly because of the way you say them."

He also made contributions to numismatics, the collection of antiquities, and bringing neural science to psychoanalysis, and these are only the areas of interest that I was aware of. He shared these interests with his friends, and he infected us all with his unpretentious, informed enthusiasm.

What is remarkable about Jimmy's accomplishments and enthusiasms is that he managed to be so creative even though his life was not easy. From his youth on, Jimmy was ill at times and down at others. But he always bounced back. A lot of this resilience was intrinsic to Jimmy. He had a genuinely optimistic view of the future. But he also benefited greatly from his family, from his children Peter and Daisy, whom he adored and who adored him, and from Fran, his first wife.

Fran's death was very hard for Jimmy, but then he met Cathy, and she fulfilled his later life beyond his wildest dreams. I am sure that in the last year he fought every day to stay alive because it allowed him to spend one more day with Cathy. In a routine conversation with Cathy a few weeks ago, she said to me, "Jimmy and I are having a wonderful time these days. He is so buoyant and happy. It is like a honeymoon."

If one has to say farewell after a full, creative, and generous life, probably the best way to say it is after a honeymoon at age 74 .

\section{Eric R. Kandel}

Division of Neurobiology and Behavior, Columbia University College of Physicians and Surgeons, New York, New York, USA. erk5@columbia.edu. 